\title{
Struktur Komunitas Ikan pada Ekosistem Mangrove di Desa Basule Kecamatan Lasolo Kabupaten Konawe Utara
}

\author{
Sandra Nolan ${ }^{1 *}$, Muhammad Ramli² Bahtiar $^{3}$ \\ ${ }^{1}$ Program Studi Ilmu Perikanan Program Pascasarjana Universitas Halu Oleo, Kendari. Sulawesi Tenggara \\ ${ }^{2,3}$ Fakultas Perikanan dan Ilmu Kelautan Universitas Haluo Oeo, Kendari. Sulawesi Tenggara
}

\author{
Riwayat artikel \\ Received : 18 Maret 2019 \\ Revised : 22 Mei 2019 \\ Accepted : 8 Juli 2019 \\ Published : 18 November 2019 \\ *Corresponding Author: \\ Sandra Nolan, \\ Program Studi Ilmu Perikanan \\ Program Pascasarjana \\ Universitas Halu Oleo, \\ Kendari, Sulawesi Tenggara. \\ Email: \\ sandraodong@gmail.com
}

\begin{abstract}
Abstrak : Desa Basule memiliki potensi ekosistem mangrove yang terus mengalami penerunan kualitas dan kuantitas sejalan dengan terus meningkatnya penangkapan yang merusak dan terus menurunnya komonitas ikan di daerah ekosistem mangrove, sehingga perlu dilakukan penelitian tentang kondisi sumber daya ikan yang terdapat di perairan tersebut sehingga dapat menjadi suatu informasi ilmiah yang berguna untuk pengelolaannya. Penelitian ini bertujuan untuk mengetahui komposisi ikan, menganalisa struktur komunitas ikan hubungannya dengan aspek fisika-kimia perairan di kawasan mangrove Desa Basule. Penelitian ini berlangsung selama 3 bulan bertempat di kawasan ekosistem mangrove Desa Basule. Stasiun penelitian ditentukan berdasarkan kerapatan mangrove dengan menentukan daerah mangrove kondisi tutupan padat, sedang dan jarang. Data yang dianalisis meliputi: indeks nilai penting mangrove, komposisi jenis ikan, struktur komunitas ikan dan analisis korelasi (PCA dan CA). Selama penelitian jumlah total ikan yang berhasil diidentifikasi dari ketiga stasiun di daerah ekosostem mangrove sebanyak 17 jenis dari 14 famili dan 14 genus. Nilai keanekaragaman tergolong rendah sampai sedang dengan kisaran 0,580-1,552, nilai keseragaman tergolong rendah dengan kisaran 0,130-0336 dan nilai dominansi tergolong ada dan tidak ada dominansi dengan kisaran 0,309-0,732. Hasil analisis PCA menjelaskan bahwa parameter lingkungan yang menjadi penciri adalah parameter salinitas $(0,81)$, DO $(0,97)$, nitrat $(0,97)$ dan suhu $(0,81)$. Hasil analisis CA ditemukan 3 kelompok. Kelompok I dicirikan oleh Chanos-chanos, Leiognatus sp, Parupeneus sp, Sphyraena genie, Tylosurus crocodilus dan Bibisa. Kelompok II dicirikan oleh Caranx sexfasciatus, Saurida tumbil, Periopthalmus argentiliniatus, Oreochromis mossambicus, Scatophagus argus dan Therapon theraps. Kelompok III dicirikan oleh Gires filementous, Girres oyena, Valamugil speigteri, Lutjanus sp dan Kooko.
\end{abstract}

Kata Kunci : Ekosistem Mangrove, Struktur Komunitas Ikan, Korelasi, Desa Basule

Abstract : Basule Village had a potential of mangrove ecosystems which continued in decreasing of quality and quantity in line with the increasing of destructive fishing and also declining of fish communities in the mangrove ecosystem area, so researcher needed to conduct the research about the condition of fish resources in the waters of Basule Village so that it can become a scientific information which was useful for management. This research aimed to determine the composition of fish and analyzed the structure of fish communities in relation with the physical-chemical aspects of waters in the mangrove area of Basule Village. This research was conducted for 3 months which located in the mangrove ecosystem area of Besule Village. The research station was determined based on the density of mangroves by determining the conditions of solid, medium, and rare cover in the mangrove area. Data analysis 
included the important of index value of mangrove, the composition of fish species, fish community structure, and correlation analysis (PCA and CA). During the research, the total number of fish that identified from the three stations in the mangrove ecosystem area was 17 species from 14 families and 14 genera. The diversity value was classified as low to moderate with a range of $0.580-1.552$, the uniformity value was classified as low with a range of $0.130-0.336$ and the dominance value was classified as there was dominance and there was no dominance in the range of $0.309-0.732$. The results of the PCA analysis explained that the environmental parameters that identified were salinity (0.81), DO (0.97), nitrate (0.97) and temperature (0.81) parameters. The results of CA analysis found 3 groups. Group I was characterized by Chanos-chanos, Leiognatus sp, Parupeneus sp, Sphyraena Genie, Tylosurus Crocodilus and Bibisa. Group II was characterized by Caranx Sexfasciatus, Saurida Tumbil, Periopthalmus Argentiliniatus, Oreochromis Mossambicus, Scatophagus Argus and Therapon Theraps. Group III was characterized by Filementous Gires, Girres Oyena, Valamugil Speigteri, Lutjanus sp and Kooko.

Keywords : Mangrove Ecosystem, Fish Community Structure, Correlation, Basule Village

\section{Pendahuluan}

Ekosistem mangrove merupakan salah satu dari ekosistem tropis dengan produktifitas tinggi. (Sukardjo, 2010). Data tingkat kerusakan hutan mangrove pada 15 provinsi di Indonesia menunjukan bahwa luas hutan mangrove yang tidak rusak (2.432.418 ha) yang terdapat pada kawasan hutan (2.268.033 ha) dan yang berada diluar kawasan hutan (623.136 ha), sedangkan luas hutan mangrove yang rusak (5.901.975 ha) yang terdapat dalam kawasan hutan (1.712.462 ha) dan yang berada di luar kawasan hutan (4.189.512 ha) (Santoso, 2006).

Kualitas dan kuantitas hutan mangrove yang menurun telah mengakibatkan dampak yang sangat mengkhawatirkan, seperti abrasi yang selalu meningkat, penurunan tangkapan perikanan pantai, intrusi air laut yang semakin jauh ke arah darat, malaria dan lainnya (Rochana, 2010). Dampak ekologis akibat berkurang dan rusaknya ekosistem mangrove adalah hilangnya berbagai spesies flora dan fauna yang berasosiasi dengan ekosistem mangrove yang dalam jangka panjang akan mengganggu keseimbangan ekosistem mangrove khususnya dan ekosistem pesisir.

Beberapa sumber daya ikan yang sering ditemukan di ekosistem mangrove yaitu ikan gelodok (Periopthalmus), ikan belanak (Mugilidae), ikan kuweh (Carangidae), ikan kapasan, lontong (Gerreidae), ikan kekemek (Scianidae), ikan barakuda, alu-alu, tancak (Sphyraenidae) dan ikan-ikan dari familia Exocietidae serta Carangidae (Rausin, 2010). Data hasil tangkapan dari Dinas Kelautan dan Perikanan Konawe Utara tahun
2015 menunjukkan peningkatan produksi tangkapan ikan di perairan pantai setiap tahunnya. Produksi tahun 20132015 dari 4.416 ton menjadi 9,539 ton. Peningkatan jumlah produksi tersebut dikhawatirkan dapat menyebabkan menurunnya jumlah komunitas ikan di wilayah tersebut. Menurut Jaureguizar dan Milessi (2008), aktivitas manusia seperti penangkapan dan modifikasi lingkungan mempunyai dampak yang besar terhadap ekosistem. Dampak tersebut menyebabkan perubahan terhadap kelimpahan, produktivitas, dan struktur komunitas seperti perubahan dominansi jenis, spektra ukuran, dan hasil tangkapan. Penelitian tentang struktur komunitas ikan telah banyak dilakukan baik di daerah subtropis maupun tropis, termasuk di Indonesia. Salah satunya yang dilakukan oleh Rejeki et al., (2013) di Desa Bedono, Demak yang melakukan penelitian tentang struktur komunitas ikan yang dilatar belakangi oleh konversi lahan mangrove sebagai pemukiman dan tambak. Selain itu, untuk daerah Sulawesi Tenggara, penelitian sejenis pernah dilakukan oleh Asriyana et al., (2009) yang dilatar belakangi oleh aktivitas yang dilakukan di sekitar Teluk Kendari.

Desa Basule saat ini telah menjadi areal penambangan nikel yang mengkonversi areal mangrove sebagai areal tambak. Aktivitas tersebut telah berlangsung semenjak tahun 2009 dan dikhawatirkan telah berdampak secara langsung terhadap keberadaan Sumber daya ikan. Konversi lahan tersebut menyebabkan menurunnya populasi ikan dan akan berakhir pada kepunahan jika tidak dilakukan upaya konservasi. Mengingat Desa Basule memiliki potensi ekosistem 
mangrove dengan berbagai acaman kedepan sehingga perlu dilakukan penelitian tentang kondisi sumber daya ikan yang terdapat di perairan tersebut sehingga dapat menjadi suatu informasi ilmiah yang berguna untuk pengelolaannya. Penelitian ini diharapkan dapat menjadi bahan informasi ilmiah untuk menunjang sumber daya ikan di ekosistem mangrove.

\section{Bahan dan Metode}

\section{Waktu dan Tempat}

Penelitian ini berlangsung selama 3 bulan dari bulan Desember 2017 - Februari 2018, bertempat di kawasan ekosistem mangrove Desa Basule Kecamatan Lasolo Kabupaten Konawe Utara. Identifikasi sampel dan analisis kualitas air dilakukan di Laboratorium Pengujian Fakultas Perikanan dan Ilmu Kelautan
Universitas Halu Oleo Kendari Provinsi Sulawesi Tenggara.

\section{Prosedur Penelitian}

\section{Penentuan Stasiun Pengamatan}

Penentuan stasiun didasarkan atas kondisi kerapatan mangrove, yaitu:

a. Stasiun I terletak di perairan dengan kerapatan mangrove yang sedang dengan nilai kerapatan 1000 - <1500 pohon/ha.

b. Stasiun II terletak di perairan dengan kerapatan mangrove yang padat dengan nilai kerapatan > 1500 pohon /ha.

c. Stasiun III terletak pada perairan dengan kerapatan mangrove yang jarang dengan nilai kerapatan $<1000$ pohon/ha. (Gambar 1).

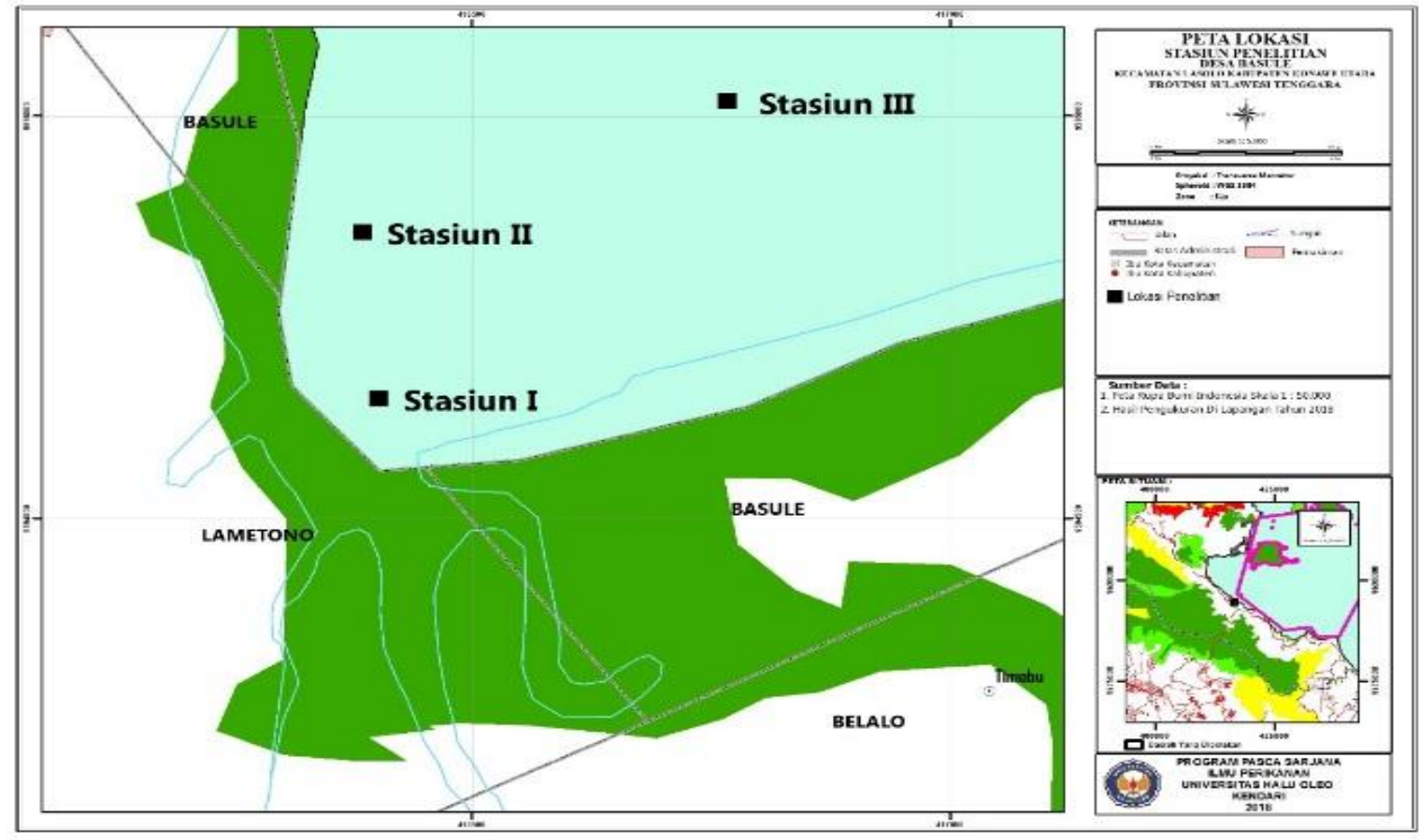

Gambar 1. Peta lokasi penelitian

\section{Pengambilan Sampel Ikan}

Metode yang digunakan dalam pengambilan sampel ikan adalah dengan menggunakan metode eksperimental fishing. Pengambilan sampel ikan dilakukan selama delapan minggu dengan interval 2 minggu, masing-masing dengan ulangan 3 kali (Rejeki et al., 2013). Sampel ikan diambil dengan menggunakan gill net atau jaring insang monofilament dan bubu.
Pengumpulan data untuk ikan dipertimbangkan berdasarkan perbedaan karateristik vegetasi mangrove. Ukuran mata jaring yang digunakan yaitu terdiri dari ukuran 1.50 inchi, $(1$ inchi $=2.54 \mathrm{~cm})$, panjang jaring 50 meter dan lebar 1.5 meter. Pemasangan alat tangkap dilakukan pada saat air pasang dan surut pada posisi tegak lurus garis pantai. Hal tersebut bertujuan agar proses penangkapan ikan akan lebih mudah. 


\section{Analisis Data}

\section{Komposisi Jenis Ikan}

Komposisi jenis ditentukan dengan cara menghitung kelimpahan setiap spesies ikan kemudian membandingkan presentase jumlahnya terhadap seluruh spesies. Komposisi jenis ikan dihitung dengan menggunakan persamaan (1) menurut (Odum, 1993), sebagai berikut:

$$
\mathrm{Kj}=\frac{\mathrm{ni}}{\mathrm{N}} \times 100 \%
$$

Keterangan:

$\mathrm{Kj}=$ komposisi jenis ikan $(\%)$

$\mathrm{Ni}=$ jumlah individu jenis ke-i (ind)

$\mathrm{N}=$ jumlah total semua individu semua spesies yang tertangkap

\section{Indeks Keanekaragaman Ikan}

Secara umum, nilai indeks $H^{\prime}$ dipengaruhi oleh jumlah spesies dan jumlah individu per spesies. Keanekaragaman ikan dihitung menggunakan rumus Shannon-Wienner (Odum, 1993), yaitu:

$$
\mathrm{H}^{\prime}=-\sum_{i=1}^{s} \mathrm{Pi} \ln \mathrm{Pi}
$$

Keterangan:

$\mathrm{H}^{\prime}=$ nilai keanekaragaman jenis Shannon-Wienner

$\mathrm{Pi}=n \mathrm{n} / \mathrm{N}$

$\mathrm{Ni}=$ jumlah individu spesies ke- $i$

$\mathrm{N}=$ jumlah total individu per titik pengambilan sampel

$\mathrm{s}$ = banyaknya jenis

Nilai indeks keanekaragaman Shannon-Wiener berkisar antara $0-\infty$ dengan kriteria pengkategorian tergantung dari nilai $\mathrm{H}^{\prime}$ yang diperoleh:

$\mathrm{H}^{\prime}<0,8$ : keanekaragaman rendah

$0,8 \leq \mathrm{H}^{\prime} \leq 1,4 \quad$ : keanekaragaman sedang

$\mathrm{H}^{\prime}>1,4 \quad$ : keanekaragaman tinggi

\section{Indeks Keseragaman Ikan}

Keseragaman jenis dihitung dengan menggunakan persamaan (3) menurut Odum (1993) sebagai berikut :

$$
\mathrm{E}=\frac{\mathrm{H}^{\prime}}{\ln \mathrm{S}}
$$

Keterangan:

$\mathrm{E} \quad=$ indeks keseragaman jenis Evenness

$\mathrm{H}^{\prime}$ = indeks keanekaragaman jenis Shannon-Wienner

$\mathrm{S} \quad=$ jumlah spesies

Menurut Krebs (1989), Indeks keseragaman berkisar antara $0-1$, yaitu:
E $>0,6 \quad$ : keseragaman spesies tinggi

$0,4 \leq \mathrm{E} \leq 0,6$ : keseragaman spesies sedang

$\mathrm{E}<0,4 \quad:$ keseragaman spesies rendah

4. Indeks Dominansi Ikan

Indeks dominansi menunjukkan adanya satu atau lebih spesies yang mempunyai peranan yang jauh lebih besar terhadap komunitas dan lingkungan. Indeks dominansi ikan dihitung dengan menggunakan persamaan (4) sebagai berikut :

$$
\mathrm{C}=\sum_{i=1}^{S}\left(\frac{\mathrm{ni}}{\mathrm{N}}\right)^{2}
$$

Keterangan:

$\mathrm{C}=$ indeks dominansi

$\mathrm{Ni}=$ jumlah individu ke-i

$\mathrm{N}=$ jumlah total individu

$\mathrm{S}$ = banyaknya jenis

Kriteria Indeks Dominansi yaitu:

$0<\mathrm{C} \leq 0,5$ : tidak ada jenis yang mendominansi.

$0,5<\overline{\mathrm{C}} \leq 1$ : terdapat jenis yang mendominansi

\section{Analisis Komponen Utama (Principal Component} Analysis, PCA)

Karateristik ekologi mangrove berdasarkan variasi parameter fisik, kimia dan biologi pada tiap stasiun, dianalisis dengan menggunakan suatu analisis statistik mutlivariabel yang didasarkan pada analisis komponen utama (principal component analysis, PCA) (Bengen, 2004). Analisis komponen utama merupakan suatu teknik mereduksi data multivariat (multivariable) yang mengubah (mentranformasi) suatu matriks data/asli menjadi suatu set kombinasi linier yang lebih sedikit akan tetapi menyerap sebagian besar jumlah varian dari data awal (Johnson \& Wichern, 1982).

\section{Hasil dan Pembahasan}

\section{Komposisi Jenis}

Selama penelitian jumlah total ikan yang berhasil disensus dari ketiga stasiun di daerah ekosostem mangrove sebanyak 17 jenis dari 14 famili dan 14 genus yang berhasil teridentifikasi. Jenis-jenis ikan yang dijumpai disajikan pada Gambar 2.

Berdasarkan Gambar 2, tercatat ada 17 jenis ikan yang terdapat di wilayah ekosistem mangrove selama penelitian dengan jenis ikan yang dominan yaitu jenis ikan putih (Caranx sexfasciatus) dari famili Carangidae dengan nilai persentasi jumlah individu dari keselurah individu mencapai $45,77 \%$. 


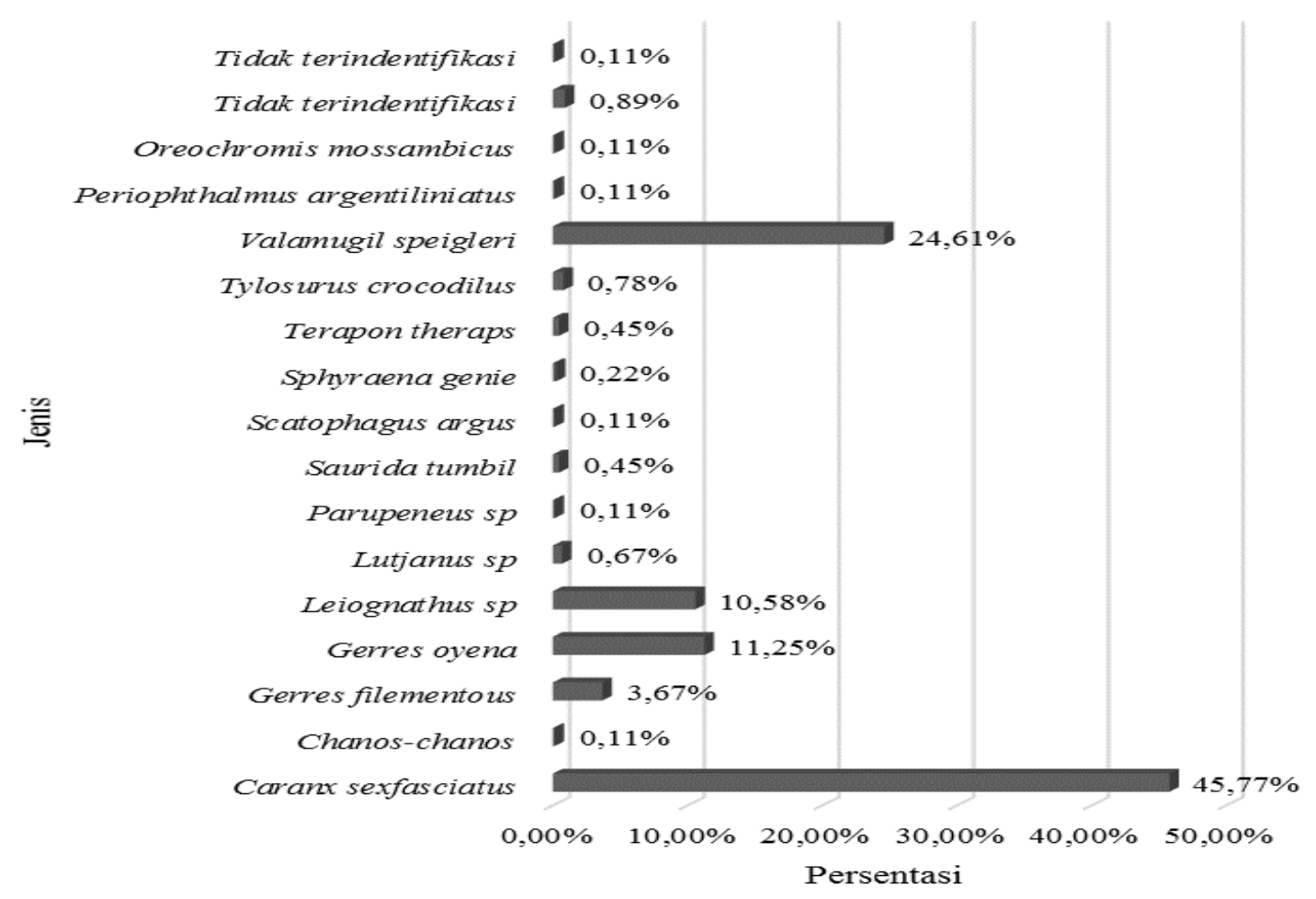

Gambar 2. Persentase kelimpahan jumlah individu setiap jenis ikan yang ditemukan selama penelitian

\section{Indeks Ekologi}

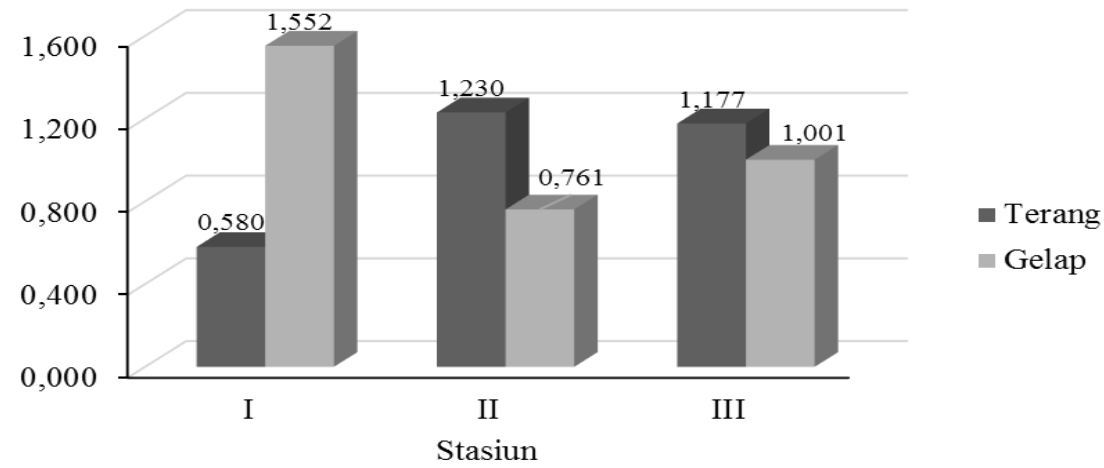

Gambar 3. Diagram keanekaragaman ikan pada lokasi penelitian 


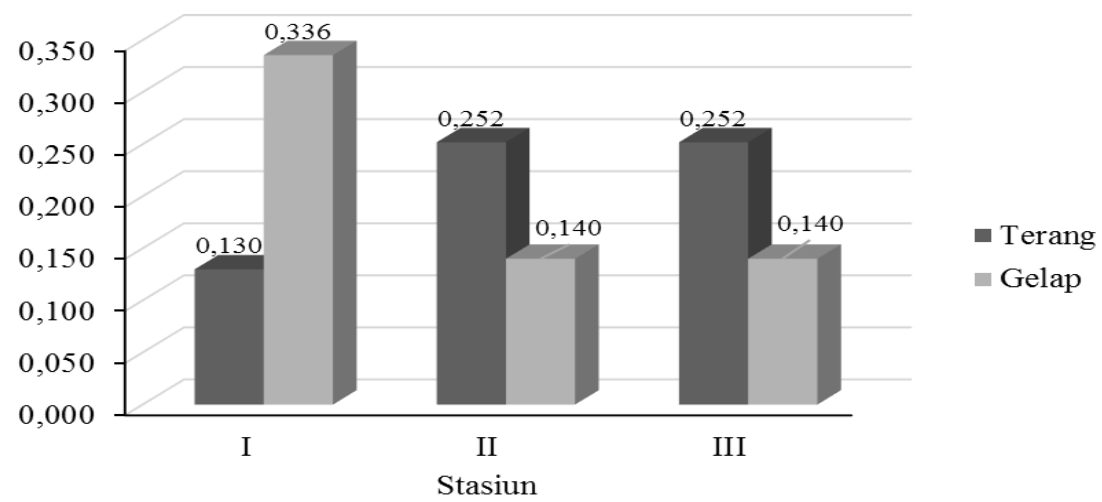

Gambar 4. Diagram keseragaman ikan pada lokasi penelitian

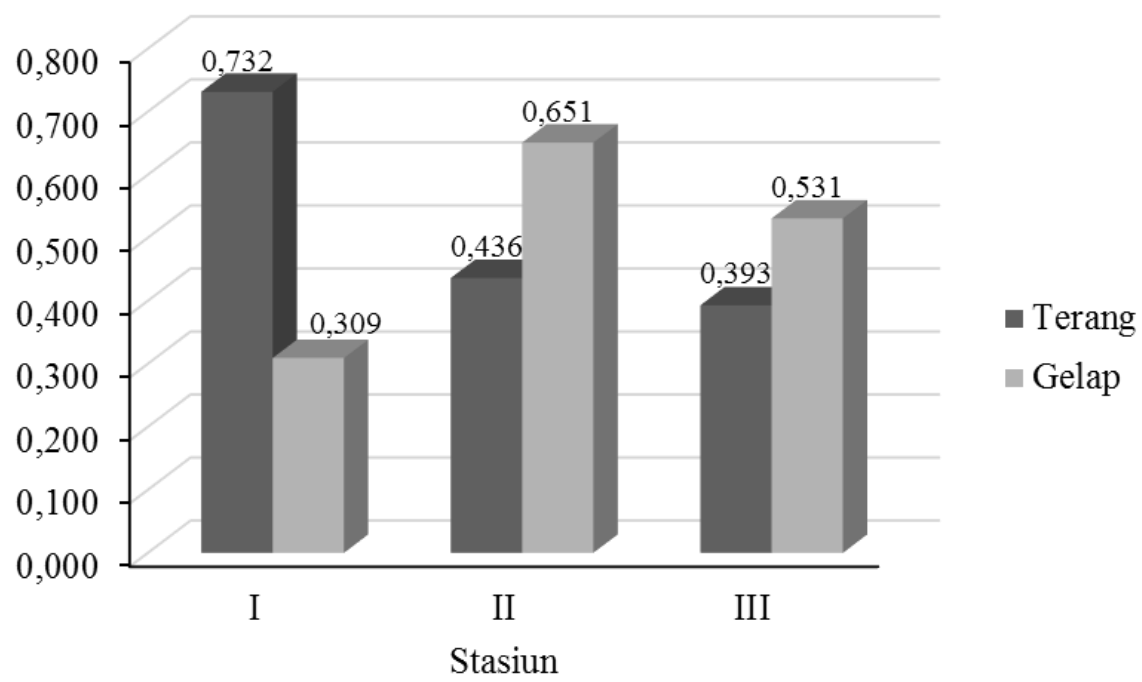

Gambar 5. Diagram dominansi ikan pada lokasi penelitian

Nilai keanekaragaman, keseragaman dan dominansi dapat menunjukkan suatu keseimbangan dalam suatu pembagian individu tiap jenis (Odum, 1996) (Gambar 3).

Nilai indeks keanekaragaman yang diperoleh tergolong rendah sampai sedang dengan kisaran 0,5801,552. Nilai indeks keseragaman yang diperoleh tergolong rendah dengan kisaran 0,130-0336. Nilai indeks dominansi yang diperoleh tergolong ada dan tidak ada dominansi dengan kisaran 0,309-0,732 (Gambar 3, 4 dan 5).
3. Analisis Hubungan Analisis Korelasi Antar Parameter Kualitas Perairan Terhadap Stasiun

Biplot (axes F1 and F2: 100,00 \%)

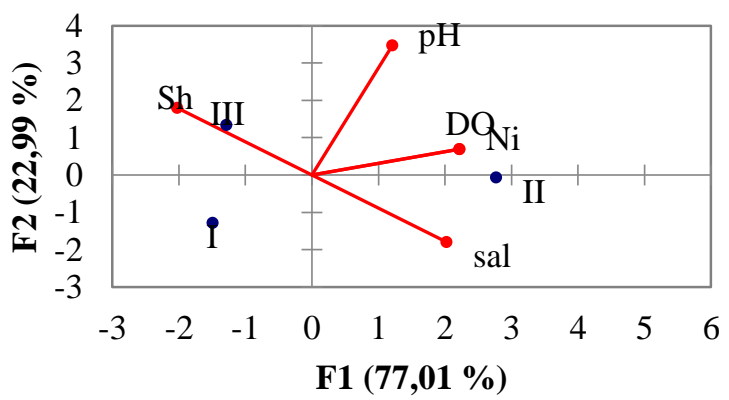

Gambar 6. Korelasi antar parameter kualitas perairan dengan stasiun penelitian 
Adanya pengelompokkan setiap stasiun memberikan gambaran setiap parameter yang menjadi penciri dari masing-masing stasiun. Beberapa parameter lingkungan mempunyai korelasi dengan kondisi stasiun (Gambar 6).

Hasil analisis Principal Component Analysis (PCA) antar parameter kualitas perairan terhadap stasiun memberikan informasi pemusatan cukup dengan sumbu F1 dan F2 masing-masing sebesar $77.01 \%$ dan $22.99 \%$ dari ragam total sebesar $100 \%$. Grafik korelasi pada kedua sumbu F1 dan F2, memberikan informasi parameter kualitas air berperan penting terhadap terbentuknya pengelompokkan di setiap stasiun. Hasil analisis memberikan informasi terkait parameter lingkungan yang menjadi penciri disetiap stasiun sekaligus mempengaruhi kelimpahan ikan. Pada sumbu F1 dicirikan oleh parameter salinitas $(0,81)$, DO $(0,97)$, Nitrat $(0,97)$ dan suhu $(0,81)$ pada stasiun I dan II. Sedangkan pada Sumbu F2 dicirikan oleh parameter $\mathrm{pH}(0.71)$ pada stasiun III.

\section{Analisis Faktorial Koresponden Komposisi Ikan Berdasarkan Stasiun Penelitian}

Analisis Faktorial Koresponden, memberikan informasi mengenai sebaran spasial yang terpusat pada sumbu F1 dan F2, yang masing-masing sumbu menjelaskan $55,96 \%$ dan $44,04 \%$ dari ragam totalnya. Kedua sumbu faktorial secara spasial terbagi menjadi 3 kelompok yang mewakili setiap stasiun. Setiap stasiun ditemukan beberapa jenis ikan yang berasosiasi dengan satu atau lebih sub stasiun yang dikarakteristikkan oleh beberapa parameter lingkungan yang sekaligus merupakan pembeda dengan stasiun lain (Gambar 7).

Symmetric plot (axes F1 and F2: 100,00\%)

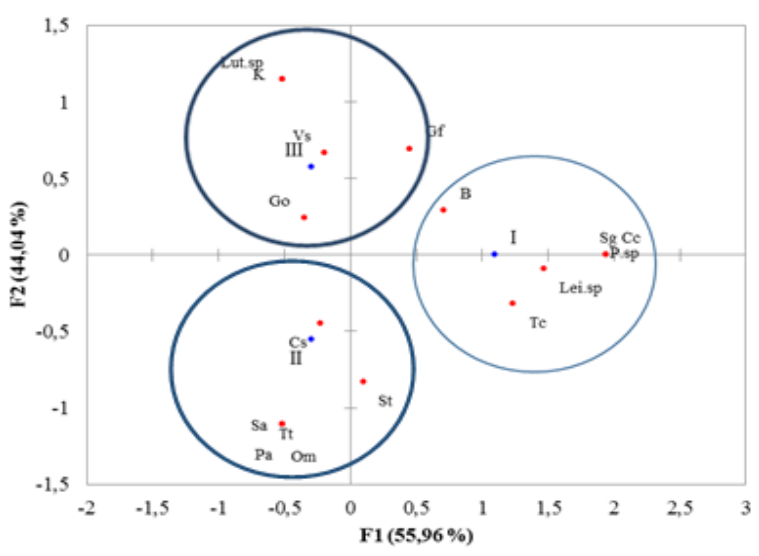

$\cdot$ Columns - Rows

Gambar 7. Grafik analisis faktorial koresponden komposisi ikan berdasarkan stasiun penelitian
Keterangan :

$\begin{array}{llll}\mathrm{Cs} & : \text { Caranx sexfasciatus } & \mathrm{Vs} & : \text { Valamugil speigleri } \\ \mathrm{Cc} & : \text { Chanos-chanos } & \mathrm{B} & : \text { Bibisa } \\ \mathrm{Gf} & : \text { Gerres flementous } & \mathrm{Pa} & : \text { Periophthalmus argentiliniatus } \\ \mathrm{Go} & : \text { Gerres oyena } & \mathrm{Om} & : \text { Oreochromis mossambicus } \\ \text { Lei.sp } & : \text { Leiognathus } s p & \mathrm{Sa} & : \text { Scatophagus argus } \\ \mathrm{P.sp} & : \text { Parupeneus } s p & \mathrm{Tt} & : \text { Terapon theraps } \\ \mathrm{St} & : \text { Saurida tumbil } & \mathrm{Lut} . \mathrm{sp} & : \text { Lutjanus } s p \\ \mathrm{Sg} & : \text { Sphyraena genie } & \mathrm{K} & : \text { Kooko } \\ \mathrm{Tc} & : \text { Tylosurus crocodilus } & & \end{array}$

1) Komposisi Jenis

Selama penelitian jumlah total ikan yang berhasil disensus dari ketiga stasiun di daerah ekosostem mangrove sebanyak 17 jenis. Jenis-jenis ikan yang dijumpai terdiri dari ikan putih (Caranx sexfasciatus), bandeng (Chanos-chanos), kapas-kapas 1 (Girres oyena), kapas-kapas 2 (Gires filementous), bete-bete (Leiognatus sp), katamba (Lutjanus sp), biji nangka (Parupeneus sp), ikan buaya (Saurida tumbil), titang (Scatophagus argus), alu-alu (Sphyraena genie), kerongkerong (Therapon theraps), sori (Tylosurus crocodilus), belanak (Valamugil speigteri), glodok (Periopthalmus argentiliniatus), bibisa (tidak terindentifikasi), mujair (Oreochromis mossambicus) dan kooko (tidak terindentifikasi).

\section{2) Indeks Ekologi Indeks Keanekaragaman}

Hasil pengamantan menunjukkan bahwa stasiun I yaitu, pada saat pengambilan data dibulan terang keanekaragaman jenis ikan pada lokasi penelitian dengan nilai 0,58 (kategori rendah), sedangkan pada saat bulan gelap jenis ikan pada lokasi penelitian dengan nilai 1,552 (kategori sedang). Pada stasiun II didapat nilai keanekaragaman sedang yaitu 1,23 pada waktu pengamatan bulan terang, sedangkan nilai keanekaragaman yang rendah yaitu 0,761 pada pengamatan bulan gelap. Pada stasiun 3 didapat nilai keanekaragaman rata-rata sedang, baik pada saat bulan terang maupun pada bulan gelap. Dengan nilai keanekaragaman pada saat bulan terang yaitu 1,177 dan pada saat bulan gelap yaitu 1,001. Rendahnya keanekaragaman pada semua stasiun menunjukkan komunitas memiliki kompleksitas rendah, karena dalam komunitas tidak banyak terjadi interaksi antar jenis. Komunitas dengan keanekaragaman jenis rendah, sedikit interaksi antar jenis yang melibatkan transfer energi, predasi, dan kompetisi. Odum (1996) menjelaskan keanekaragaman jenis cenderung rendah dalam ekosistem yang secara fisik terkendali (sasaran faktor pembatas fisika kimia yang kuat).

Perbedaan nilai keanekaragaman setiap stasiun tidak menunjukkan data yang signifikan. Hasil analisis menunjukan, nilai rata-rata keanekaragaman tertinggi berada pada stasiun III dengan nilai yaitu 1,089, kemudiaan stasiun I dengan nilai yaitu 1,066 dan stasiun 
II dengan nilai yaitu 0,995. Tingginya nilai keanekaragaman pada stasiun III tidak semata-mata dipengaruhi oleh kondisi kerapatan mangrove melainkan dipengaruhi oleh seragamnya jumlah individu setiap spesies, meskipun jumlah spesies relatife sedikit dibandingkan dengan stasiun lain, namun tidak ada yang mendominasi. Hal ini sesuai dengan pernyataan AmboRappe et al., (2013) menemukan adanya kerapatan vegetasi mangrove yang berbeda akan turut memengaruhi struktur komunitas ikan secara spasial. Selanjutnya Gunarto (2005), menyatakan, suatu komunitas dikatakan mempunyai keanekaragaman dan keseragaman jenis yang tinggi apabila terdapat banyak spesies dengan jumlah individu masing-masing spesies yang relatif merata, maka bila suatu komunitas hanya terdiri dari sedikit spesies dengan jumlah individu yang tidak merata atau ada beberapa yang dominan, komunitas tersebut tidak dapat dikatakan keanekaragaman atau keseragaman yang tinggi. Keanekaragaman yang terdapat di perairan Desa Basule tergolong rendah. Hal ini sama ditemukan di Perairan Teluk Kendari yang memiliki keanekaragaman jenis ikan yang bervariasi. Keanekaragaman jenis rendah di semua stasiun dan waktu pengambilan contoh (0,51-1,97), kecuali pada Stasiun III pada bulan Oktober mempunyai keanekaragaman jenis yang lebih tinggi $(2,25)$ (Asriyana et al., 2009).

Selain perbedaan nilai keanekaragaman secara spasial, hasil analisis juga menggabarkan perbedaan nilai keanekaragaman secara temporal yaitu pada saat bulan terang dan bulan gelap. Nilai rata-rata keanekaragaman tertinggi terdapat pada bulan gelap yaitu 1,105 sedangkan bulan terang yaitu 0,995 . Sementara itu, melimpahnya spesies ikan pada bulan gelap diduga terkait sifat optik ikan yang terdistribusi terpusat menuju titik cahaya. Hal ini sesuai dengan pernyataan Ongkers (2006), menyatakan bahwa perbedaan yang nyata dari bulan terang dan gelap mengindikasikan bahwa pada bulan gelap, ikan-ikan akan berdistribusi terpusat menuju titik cahaya, karena ikan-ikan dengan fototaksis positif mengarah ke cahaya lampu (light fishing) dan menyebar merata pada kedalam tertentu pada saat bulan terang. Selanjutnya Van Oostenbrugge (2003) yang meneliti tentang perikanan dengan bantuan cahaya (light fishing) di sekitar pulau Ambon dan Lease menyimpulkan bahwa ikan-ikan akan berlimpah pada bulan gelap. Begitupun apa yang terjadi pada ketidak perbedaan antar lokasi menunjukkan bahwa kelimpahan jenis belum mencapai suatu ambang yang memungkinkan perbedaan jumlah jenis. Menurut Rausin (2010), besarnya nilai kelimpahan ikan pada malam bulan gelap cenderung lebih tinggi dari pada malam bulan terang. Cahaya bulan yang terang dapat memudahkan ikan predator atau hewan predator lainnya untuk memangsa ikan-ikan yang ada, sehingga kemungkinan ketika malam bulan terang ikan cenderung mencari tempat yang aman. Akibatnya, jumlah ikan yang ditangkap pada malam bulan terang cenderung lebih sedikit dibandingkan pada malam bulan gelap.

\section{3) Indeks Keseragaman}

Nilai indeks keseragaman setiap stasiun memiliki nilai yang rendah dan nilainya cenderung mirip antara stasiun I, II dan III. Bulan terang nilai keseragaman yaitu stasiun I $(0,130)$, stasiun II $(0,252)$ dan stasiun III $(0,252)$. Sedangkan pada bulan gelap memiliki nilai yaitu stasiun I $(0,336)$, stasiun II $(0,140)$ dan stasiun III $(0,140)$ (Gambar $6)$.

Indeks keseragaman pada pada lokasi penelitan ditiap stasiun masuk dalam kriteria populasi rendah. Keseragaman ikan yang rendah diperkirakan karena ada spesies yang mendominasi di wilayah tersebut sehingga spesies lain menjadi terganggu. Hal ini mengakibatkan struktur komunitas menjadi kurang stabil atau rendah. Menurut kriteria Ambarita (2009), bahwa nilai indeks keseragaman pengamatan dibagi menjadi kriteria dengan kondisi rendah, kondisi labil dan stabil. Kriteria pertama menyatakan bahwa kelompok komunitas keseragaman suatu organisme dimana, $0<\mathrm{E}<0,50$ (keseragaman rendah), kriteria kedua nilai $0.50<\mathrm{E}=0.75$ (keseragaman sedang), sedang kriteria ketiga yaitu dengan nilai indeks keseragaman $0.75<\mathrm{E}=1.00$ (keseragaman tinggi).

Nilai keseragaman setiap stasiun tidak menunjukkan perbedaan hasil yang signifikan. Hasil analisis menunjukkan, nilai rata-rata keseragaman tertinggi berada pada stasiun I dengan nilai yaitu 0,233 , kemudiaan stasiun II dan III dengan nilai yaitu 0,196 . Tingginya nilai keseragaman pada stasiun I tidak sematamata dipengaruhi oleh kondisi kerapatan mangrove melainkan dipengaruhi oleh seragamnya jumlah individu setiap spesies, meskipun jumlah spesies relative sedikit dibandingkan dengan stasiun II, namun tidak ada yang mendominasi. Hal ini sesuai dengan pernyataan AmboRappe et al (2013) menemukan adanya kerapatan vegetasi mangrove yang berbeda akan turut memengaruhi struktur komunitas ikan secara spasial. Selanjutnya Gunarto (2005), menyatakan, suatu komunitas dikatakan mempunyai keanekaragaman dan keseragaman jenis yang tinggi apabila terdapat banyak spesies dengan jumlah individu masing-masing spesies yang relatif merata, maka bila suatu komunitas hanya terdiri dari sedikit spesies dengan jumlah individu yang tidak merata atau ada beberapa yang dominan, komunitas tersebut tidak dapat dikatakan keanekaragaman atau keseragaman yang tinggi.

Selain perbedaann nilai keseragaman secara spasial, hasil analisis juga menggabarkan perbedaan nilai keseragaman secara temporal yaitu pada saat bulan terang dan bulan gelap. Nilai rata-rata keseragaman tertinggi terdapat pada bulan terang yaitu 0,211 sedangkan bulan 
bulan yaitu 0,205 . Sementara itu, lebih meratanya jumlah individu ikan setiap jenis pada bulan terang diduga terkait sifat optik ikan yang terdistribusi ke arah sebaran cahaya sehingga jumlah individu setiap spesies menjadi seragam. Hal ini sesuai dengan pernyataan Ongkers (2006), menyatakan bahwa perbedaan yang nyata dari bulan terang dan gelap mengindikasikan bahwa pada bulan gelap, ikan-ikan akan berdistribusi terpusat menuju titik cahaya, karena ikan-ikan dengan fototaksis positif mengarah ke cahaya lampu (light fishing) dan menyebar merata pada kedalam tertentu pada saat bulan terang. Selanjutnya menurut Van Oostenbrugge (2003) yang meneliti tentang peikanan dengan bantuan cahaya (light fishing) di sekitar pulau Ambon dan Lease menyimpulkan bahwa ikan-ikan akan berlimpah pada bulan gelap. Begitupun apa yang terjadi pada ketidak perbedaan antar lokasi menunjukkan bahwa kelimpahan jenis belum mencapai suatu ambang yang memungkinkan perbedaan jumlah jenis. Supriharyono (2000), menjelaskan bahwa ikan merupakan organisme yang aktif pada malam hari dan cenderung tertarik pada cahaya. Namun ketertarikan ikan terhadap cahaya menyebakan ikan menyebar ke arah sumber cahaya sehingga hasil tangkapan menjadi berkurang.

\section{4) Indeks Dominansi}

Menurut Gunarto (2005), bahwa kelompok ikan yang memiliki jumlah individu dan jenis yang tidak seragam atau ada yang dominan sedangkan yang lainnya jumlahnya sedikit, maka nilai $\mathrm{D}$ (dominansinya) akan tinggi begitu pula sebaliknya. Berdasarkan pernyataan tersebut maka dapat dilihat bahwa jumlah individu yang terdapat pada stasiun III tidak merata namun memiliki keanekaragaman yang sedang sehingga mengakibatkan dominansinya rendah.

Berdasarkan hasil analisis perhitungan nilai dominansi setiap stasiun menunjukan nilai kategori dominansi rendah sampai sedang dengan nilai rata-rata pada stasiun I yaitu 0,520 , stasiun II yaitu 0,543 dan stasiun III yaitu 0,462. Menurut Odum (1996) indeks dominansi tinggi (jika nilai $0,75<\mathrm{D}=1,00$ ), indeks dominansi sedang (jika nilai $0,5<\mathrm{D}=0,7$ ) dan indeks dominansi rendah (jika nilai $0<\mathrm{D}=0,5$ ). Untuk nilai $\mathrm{D}$ $=1$ berarti terdapat jenis yang mendominasi jenis lainnya atau komunitas berada dalam kondisi labil karena terjadi tekanan ekologis. Selanjutnya Indriyanto (2006) menambahkan bahwa apabila indeks dominansi tinggi, maka dominansi (penguasaan) terpusat (terdapat) pada satu spesies, namun bila nilai indeks dominansi rendah, maka dominansi terpusat (terdapat) pada beberapa spesies.

Hasil analisis menjelaskan bahwa perbedaan dominansi secara signifikan terdapat pada stasiun I pada saat bulan terang yang termaksud dalam kategori dominansi yang tinggi (Gambar 9). Hal ini disebakan jenis ikan Leiognatus sp mendominasi di stasiun tersebut, hal ini juga terjadi di stasiun II pada bulan gelap dengan jenis ikan yang mendominasi yaitu Caranx sexfasciatus. Umumnya jenis ikan Leiognatus sp dan Caranx sexfasciatus merupakan jenis ikan ekonomis penting dan menjadi target penangkapan oleh para nelayan setempat.

Ketegori rendah sampai sedangnya indeks dominansi tersebut memiliki arti bahwa kondisi komunitas di wilayah tersebut masih stabil, karena bila suatu kawasan terjadi dominasi suatu spesies maka kawasan tersebut dapat dikatakan sedang mendapat tekanan ekologis. Wizurai et al. (2012), menyatakan bahwa penghilangan satu spesies dominan dalam suatu komunitas sering kali terjadi karena pengaruh manusia terhadap komunitas. Dhahiyat et al. (2009) menambahkan bila dalam suatu struktur komunitas biota yang diamati terdapat spesies yang mendominasi. Hal ini menunjukkan bahwa kondisi struktur komunitas berada dalam keadaan labil atau sedang terjadi tekanan ekologis.

5) Analisis Hubungan Analisis Korelasi Antar Parameter Kualitas Perairan Terhadap Stasiun

Tabel eigenvalues dan tabel factor loadings menunjukkan bahwa faktor utama 1 (F1) merepresentasikan sekitar $77,01 \%$ dari keragaman data. Hasil analisis memberikan informasi terkait parameter lingkungan y ang menjadi penciri disetiap stasiun sekaligus mempengaruhi kelimpahan ikan. Pada sumbu F1 dicirikan oleh parameter salinitas $(0,81)$, DO $(0,97)$, Nitrat $(0,97)$ dan suhu $(0,81)$ pada stasiun I dan II. Sedangkan pada Sumbu F2 dicirikan oleh parameter $\mathrm{pH}$ (0.71) pada stasiun III. Stasiun yang mempunyai kemiripan ciri adalah stasiun I dan II (F1), sedangkan stasiun III (F2) tidak mempunyai kemiripan dengan stasiun lain.

Hasil analisis PCA memberikan informasi bahwa setiap variabel mempunyai korelasi pada setiap sumbunya. Parameter salinitas, $\mathrm{pH}$, oksigen terlarut, nitrat dan suhu mempunyai kontribusi yang besar pada masingmasing sumbu F1 dengan nilai masing-masing 21,028 $25,225,25,242$ dan 21,028, sedangkan parameter pada sumbu F2 yaitu pH dengan kontribusi 61,938. Besaran setiap nilai kontribusi menunjukkan parameter tersebut memiliki nilai penting dalam menentukan distribusi dan kehadiran komposisi ikan disetiap stasiun.

Stasiun I letaknya dekat garis pantai, berada dekat dengan pemukiman serta merupakan daerah vegetasi mangrove dengan kerapatan sedang dicirikan oleh persentase salinitas, oksigen terlarut, nitrat dan suhu yang tinggi. Stasiun II letaknya berada di kawasan mangrove dengan kategori kerapatan mangrove padat dicirikan sama dengan stasiun I pada sumbu F1. Stasiun III letaknya jauh garis pantai, berada jauh dengan pemukiman serta 
merupakan daerah vegetasi mangrove dengan kerapatan jarang dicirikan oleh persentase $\mathrm{pH}$ yang tinggi pada sumbu F2.

Berbeda halnya dengan penelitian Schaduw (2018), menyatakan bahwa tabel eigenvalues dan tabel factor loadings menunjukkan bahwa faktor utama 1 (F1) merepresentasikan sekitar 79,33\% dari keragaman data dengan variabel penciri utamanya yaitu suhu (nilai factor loadings sebesar 0,3912) dan TSS (nilai factor loadings sebesar -0,3878). Namun variabel TSS berkorelasi negatif, dimana dengan meningkatnya TSS di sisi lain justru dapat menurunkan suhu perairan. Faktor utama 2 (F2) merepresentasikan 14,22\% dari keragaman data, dengan variabel pencirinya PO4-P dengan nilai factor loadings $70,16 \%$, sedangkan faktor utama 3 (F3) merepresentasikan $6 \%$ dari keragaman data, dengan variabel pencirinya salinitas dengan factor loading $71 \%$, karena direpresentasikan dengan karakteristik faktor loadings yang berbeda, maka tidak terdapat kaitan satu sama lain, hal ini artinya karakteristik bersifat independen. Selain itu, kajian Ulqodry et al., (2010) terhadap karakteristik perairan mangrove Tanjung Apiapi, untuk Stasiun I (daerah laut) dicirikan oleh suhu, salinitas, DO dan $\mathrm{pH}$ yang tinggi, Stasiun II (daerah muara) lebih dicirikan oleh nilai TOM dan TSS yang tinggi sedangkan Stasiun III (daerah belakang muara/sungai) sedikit dicirikan oleh parameter fisikakimia air dibandingkan dengan stasiunstasiun yang berada di daerah laut dan muara. Kajian Poedjirahajoe (2017) yang menggunakan PCA dalam menganalisa distribusi spasial vegetasi di Pemalang menggunakan variebel jenis mangrove dan kualitas air sebagai parameter penelitian, hasilnya adalah sebaran spasial karakteristik faktor habitat mangrove pada setiap stasiun pengamatan di Pantai Utara Pemalang membentuk tiga cluster dengan karakteristik habitat yang berbeda. Cluster 1 terdiri dari $R$. mucronata dan $S$. alba dengan karakteristik habitat berupa $\mathrm{pH}$, salinitas, dan tebal lumpur yang rendah, suhu yang sedang, dan oksigen terlarut yang tinggi. Cluster 2 tersusun oleh Acanthus ilicifolius, Avicennia alba, dan $R$. Apiculata dengan karakteristik habitat berupa suhu yang rendah serta tebal lumpur, $\mathrm{pH}$, oksigen terlarut, dan salinitas yang sedang. Cluster 3 berupa Avicennia marina dengan karakteristik habitat berupa $\mathrm{pH}$, salinitas, suhu, dan tebal lumpur yang tinggi serta oksigen terlarut yang rendah.

6) Analisis Faktorial Koresponden Komposisi Ikan Berdasarkan Stasiun Penelitian

Nilai korelasi setiap jenis ikan terhadap stasiun memiliki nilai kontribusi yang berbeda setiap sumbunya. Terdapat 2 sumbu yaitu F1 dan F2 memiliki nilai korelasi terhadap komposisi ikan pada setiap stasiun. Sumbu F1 dicirikan dengan komposisi ikan pada stasiun I, sedangkan F2 dicirikan komposisi ikan pada stasiun II dan III dengan nilai kontribusi setiap sumbunya masingmasing F1 yaitu 0,790, F2 yaitu 0,491 dan 0,509 .

Berdasarkan hasil analisis Correspondence Analysis (CA) ditemukan 3 kelompok dalam menentukan korelasi stasiun terhadap keberadaan ikan. Kelompok A yang merupakan stasiun I ditemukan terdistribusi beberapa jenis ikan diantaranya Chanos-chanos, Leiognatus sp, Parupeneus sp, Sphyraena genie, Tylosurus crocodilus dan Bibisa, dicirikan oleh salinitas $23,80 \%$ o oksigen terlarut $6,90 \mathrm{mg} / \mathrm{L}$, nitrat $3,05 \mathrm{mg} / \mathrm{L}$ dan suhu 28,50 ${ }^{\circ} \mathrm{C}$. Kelompok B yaitu stasiun II ditemukan terdistribusi beberapa jenis ikan diantaranya Caranx sexfasciatus, Saurida tumbil, Periopthalmus argentiliniatus, Oreochromis mossambicus, Scatophagus argus dan Therapon theraps, salinitas $24,10 \%$, oksigen terlarut 7,80 mg/L, nitrat $3,64 \mathrm{mg} / \mathrm{L}$ dan suhu $27,00{ }^{\circ} \mathrm{C}$. Kelompok C yaitu stasiun III ditemukan terdistribusi beberapa jenis ikan diantaranya Gires filementous, Girres oyena, Valamugil speigteri, Lutjanus sp dan Kooko, dicirikan oleh $\mathrm{pH} 8,10$. Nilai parameter kualitas air sebagai penciri dari stasiun tersebut tidak berkorelasi langsung terhadap hadirnya jenis-jenis ikan tersebut.

\section{Kesimpulan}

Hasil analisis Principal Component Analysis (PCA) menjelaskan bahwa parameter lingkungan yang menjadi penciri pada stasiun I da II adalah parameter salinitas $(0,81)$, DO $(0,97)$, nitrat $(0,97)$ dan suhu $(0,81)$, sedangkan pada stasiun III dicirikan oleh parameter $\mathrm{pH}$ (0,71). Hasil analisis Correspondence Analysis (CA) ditemukan 3 kelompok dalam menentukan korelasi stasiun terhadap keberadaan ikan. Kelompok I dicirikan oleh beberapa jenis ikan yang berasosiasi diantaranya Chanos-chanos, Leiognatus sp, Parupeneus sp, Sphyraena genie, Tylosurus crocodilus dan Bibisa dengan kondisi mangrove kerapatan padat. Kelompok II dicirikan oleh beberapa jenis ikan yang berasosiasi diantaranya Caranx sexfasciatus, Saurida tumbil, Periopthalmus argentiliniatus, Oreochromis mossambicus, Scatophagus argus dan Therapon theraps dengan kondisi mangrove kerapatan padat. Kelompok III dicirikan beberapa jenis ikan yang berasosiasi diantaranya Gires filementous, Girres oyena, Valamugil speigteri, Lutjanus sp dan Kooko dengan kondisi mangrove kerapatan sedang. Berdasarkan hasil penelitian dan pembahasan maka dapat disimpulkan bahwa Komposisi jenis ikan mangrove yang diperoleh pada lokasi penelitian berjumlah 17 jenis dengan total individu semua jenis sebanyak 898 dimana jenis-jenis yang medominasi diantaranya: Caranx sexfasciatus dengan persentasi $45,77 \%$, Valamugil speigteri dengan persentasi $24,61 \%$ dan Leiognatus sp, dengan persentasi $10,58 \%$, sedangkan jumlah individu terkecil yaitu jenis Chanos-chanos, Parupeneus sp, 
Scatophagus argus, Periopthalmus argentiliniatus, dan Ikan Kooko dengan persentasi $0,11 \%$. Nilai Keanekaragaman ikan tergolong dalam kategori rendah sampai sedang. Nilai keseragaman termasuk dalam kategori rendah. Nilai dominansi termaksud dalam kategori rendah sampai sedang.

\section{Ucapan Terima Kasih}

Ucapan terima kasih penulis sampaikan kepada semua pihak yang telah mendukung baik moril ataupun materil sehingga kami dapat menyelesaikan penelitian ini.

\section{Daftar Pustaka}

Ambarita, R. (2009). Keanekaragaman dan Distribusi Ikan di Hulu Sungai Asahan Porsea. [Skripsi]. Universitas Sumatera Utara. Medan.

Ambo-Rappe, R., M. N. Nessa, H. Latuconsina \& D. L. Lajus (2013). Relationship Between the Tropical Seagrass Bed Characteristics and The Structure of The Associated Fish Community. Open Journal of ecology, 3(5):331-342

Asriyana, Rahadjo, M. F., Sukimin, S., Lumban Batu, D. F. \& Kartamihardja, E. S. (2009). Keanekaragaman Ikan di Perairan Teluk Kendari Sulawesi Tenggara. Jurnal Iktiologi Indonesia, 9(2) : 97-112.

Bengen, D.G. (2000). Pedoman Teknis Pengenalan dan Pengelolaan

Ekosistem

Mangrove. Pusat Kajian Sumberdaya Pesisir dan Lautan. Institut Pertanian Bogor. Bogor. 59 hal.

Bengen, D.G. (2004). Ekosistem dan Sumberdaya Alam Pesisir dan Laut serta Prinsip Pengelolaannya. Bogor: Pusat Kajian Sumberdaya Pesisir dan Lautan, Institut Pertanian Bogor.

Gunarto (2005). Konservasi Mangrove Sebagai Pendukung Sumber Hayati Perikanan Pantai. Jurnal Litbang Pertanian.

Indriyanto (2006). Ekologi Hutan. Bumi Aksara. Jakarta. 138 hal

Johnson, R.A. \& Wichern, D.W. (1982). Applied Multivariate Statistical Analysis. Griffin. London.

Jaureguizar, A. J. \& Milessi, A. C. (2008). Assesing the Source of the Fishing Down Marine Food Web Proccess in the Argentinean-Uruguayan Common Fishing Zone. Science and Marine. 72 (1):25-36.
Krebs, C.J. (1989). Ecologycal Methodology. Harper Collins Publisher Inc, NewYork: xii + 654 hlm.

Nontji A. (2005). Laut Nusantara. Jakarta: Penerbit Djambatan.

Odum, E.P. (1993). Dasar-dasar Ekologi. Yogyakarta: Gadjah Mada University Press.

Odum, E.P. (1996). Dasar-Dasar Ekologi. Alih Bahasa. Cahyono, S. FMIPA IPB. Gadjah Mada University Press. 625p.

Ongkers (2006). Kelimpahan ikan yang tertangkap dengan jaring pantai di perairan Teluk Ambon Dalam. Fakultas Perikanan dan Ilmu Kelautan Universitas Pattimura, Ambon. Prosiding Seminar Nasional Ikan VI: 415-425.

Poedjirahajoe E, Djoko M \& F Kusuma, (2017). Penggunaan Principal Component Analysis Dalam Distribusi Spasial Vegetasi Mangrove Di Pantai Utara Pemalang. Jurnal Ilmu Kehutanan 11 : 2942 .

Rausin, A. H. (2010). Fauna Mangrove dan Interaksi di Ekosistem Mangrove.

Rejeki, S., Irwani \& Firdaus, M.H. (2013). Struktur Komunitas Ikan pada Ekosistem Mangrove di Desa Bedono, Sayung, Demak. Buletin Oseanografi Marina. 2 : 78-86.

Rochana, E. (2010). Citing Computer References. Ekosistem Mangrove dan Pengelolaanya di Indonesia. Artikel Ilmiah. http://www.irwantoshut.com/ekosistem_mangrov e. (diakses tanggal 5 Mei 2015).

Santoso, Urip (2006). Hukum Agraria dan Hak-Hak Atas Tanah, Prenada Media, Jakarta.

Schaduw, J. N. W. (2018). Distribusi Dan Karakteristik Kualitas Perairan Ekosistem Mangrove Pulau Kecil Taman Nasional Bunaken. Fakultas Perikanan dan Ilmu Kelautan, Universitas Sam Ratulangi, Manado, Sulawesi Utara, Indonesia. Majalah Geografi Indonesia Vol. 32, No.1, Maret 2018 (40 - 49).

Sukardjo, S. (2010). The South China Seas Mangroves: Ecology, Sosial and Uses, Naturaland Human Induced Stress Information's in Indonesia. 1ed. 
Ed. Research Centre for Oceanography, Jakarta, Indonesia. Ix, $177 \mathrm{pp}$.

Supriharyono (2000). Pelestarian dan Pengelolaan Sumberdaya Alam di Wilayah Pesisir Tropis. Jakarta: PT. Gramedia Pustaka Utama.

Ulqodry TZ, Dietriech GB \& Richardus FK. (2010). Karakteristik Perairan Mangrove Tanjung Api-Api Sumatera Selatan Berdasarkan Sebaran Parameter Lingkungan Perairan Dengan Menggunakan Analisis Komponen Utama (PCA). Maspari Journal $1: 16$ - 21.

Van Oostenbrugge, J.A E. (2003). Uncertainty in daily catch rate in the light fisheries around Ambon and Lease Islands: Characterisation, causes and consequencies. ( $\mathrm{PhD}$ thesis). Wegeningen University 